\title{
A SUPPLEMENTARY LIST OF FLOWERING PLANTS OCGURRING IN THE KRUGER

\author{
NATIONAL PARK
}

by

\section{P. VAN WYK*}

\begin{abstract}
A comprehensive list of the plant species occurring in the Kruger National Park, compiled in the period prior to 1956, was followed by a supplementary list covering additions up to 1960. The present article deals with those species which were discovered from 1960 onwards. Short notes on the habitat and outstanding morphological features of each species are also included.
\end{abstract}

Although the first record of plants being collected in the Kruger National Park dates back to the previous century the first publication on the flora of the region only appeared in 1937. This was an article by A. A. Obermeyer of the Transvaal Museum which dealt with a collection made by Dr. H. Lang. In 1951 this was followed by the well-known book Trees and Shrubs of the Kruger National Park by Dr. L. E. W. Codd during the compilation of which the author and others collected about 1200 different plant species in the region. Shortly afterwards the first botanist in the service of the National Parks Board (H. P. van der Schijff) undertook a comprehensive survey of the flora of the region. The result of this study was a voluminous work (including about 2000 species) on which he was granted a doctorate by Potchefstroom University for C.H.E. Unfortunately his work was never published in a complete form but extracts from it have already appeared in journals such as Koedoe, Tydskrif vir Natuurwetenskap and others. Several papers dealing with the distribution and ecology of the large mammals, reptiles, birds, etc. of the park, in which habitat descriptions were naturally included, also appeared in Koedoe and other journals.

Because a thorough knowledge of all life forms occurring in a park or nature reserve is of vital importance in its management and maintenance the search for "new" species still proceeds. The first supplement to the list compiled by Van der Schijff appeared in Koedoe 4 (Brynard). Since then, quite a number of species, including some unidentified material previously collected, could be added to the local herbarium. In the fol-

* Chief Research Officer, Kruger National Park, Private Bag 404, Skukuza 
lowing list these species are arranged according to the sequence adopted by Phillips in Genera of South African flowering plants. Properly prepared specimens of all the species mentioned are kept in the herbarium at Skukuza in the Kruger National Park.

\section{ANGIOSPERMAE}

\section{A. MONOCOTYLEDONEAE}

\section{APONOGETONACEAE}

Aponogeton junceus Lehm. ex Schlechtd.

Erect hydrophyte with long, slender petioles, linear/elliptic leaves and furcate, spike-like inflorescences. Flowers white. Grows in temporary pans in the Pumbe sandveld area on the Lebombo Mountains. (PumbeAcornhoek 2431BB). Van Wyk : 4785.

\section{GRAMINEAE}

Chrysopogon montanus Trin. var tremulus Stapf. Small, tufted, glaucous, perennial grass (up to $40 \mathrm{~cm}$ high). Vegetative parts resemble Bothriochloa insculpta (Hochst.) A. Camus. Forms homogenous stands on the dry, stony ridges in the area south of Pafuri. (Collected east of Mahlakuza pan-Pafuri 2231 AD). Van Wyk and Pienaar : 4573.

Schizachyrium exile (Hochst.) Stapf

Very rare, small ( $50 \mathrm{~cm}$ high), slender, conspicuously red, annual grass in firebreak road near Malonga spring on red Kalahari-like sand. Previously only recorded from South West Africa. (Malonga-Pafuri 2231 CD). Van Wyk and Pienaar : 4574.

\section{Hyparrhenia hirta (L.) Stapf}

This well-known, tall (up to $100 \mathrm{~cm}$ ), tufted, erect, perennial grass was found in granite soil near Pretoriuskop restcamp. Rare in the park. (Kamban-Komatipoort $2531 \mathrm{AB}$ ). Van Wyk : 4663.

Panicum heterostachyum Hack.

A very small and slender grass found on damp soil underneath trees north-east of Punda Milia. (Shipale hot spring-Pafuri 2231 CA). Pienaar : 4510.

Setaria perennis Hack.

Tufted perennial grass with culms up to $60 \mathrm{~cm}$ high. Grows in sandy, granite soil south of Pretoriuskop restcamp (Rhino enclosure). Rare in the park. Relished by square-lipped rhino. (Pretoriuskop-Komatipoort $2531 \mathrm{AB})$. Van Wyk and Fairall : 4564.

Aristida bipartita (Nees) Trin. et Rupr.

Small, tufted, perennial grass up to $25 \mathrm{~cm}$ high. Found on granite soil near Pretoriuskop. (Kamban-Komatipoort $2531 \mathrm{AB}$ ). Van Wyk : 4811.

Sporobolus pectinatus Hack.

Tufted perennial grass with horizontal rhizome on granitic soil near Pretoriuskop restcamp. (Kamban-Komatipoort 2531 AB). Van Wyk : 4809. 


\section{IRIDACEAE}

Schizostylus coccinea Backh. and Harvey

Erect, bulbous plant with purple flowers. Grows in granitic soilmostly in shade. (Malelane-Komatipoort 2531 AD). Brynard and Pienaar : 4379.

\section{B. DICOTYLEDONAE}

\section{MORACEAE}

Ficus natalensis (Miq.) Hochst.

Strangling fig tree of which only two specimens have been discovered thus far-both in riverine forest on the bank of the Levubu River northwest of Punda Milia. The leaves are obovate/elliptic, dark-green and shining. The small, reddish figs are borne singly or in pairs in the leaf axils. (Levuvhu near Shipakweni spring-Messina 2230 DB). Van Wyk: 4767.

Ficus sp cf. F. craterostoma Warb. ex Mildbr. and Burret.

A single young tree in the same locality as the above-mentioned fig could not be identified with absolute certainty due to a lack of reproductive material.

\section{LORANTHACEAE}

Loranthus ngamicus Sprague.

Rare parasitic plant with distinctive hairy leaves and flowers. Flowers pale yellow-green. Only found on Ostryoderris stuhlmannii Dun. Therefore only occurs in the sandveld areas in the north of the park, i.e. in the vicinity of Punda Milia and in Nwambiya-especially in the latter. (Nwambiya-Pafuri $2231 \mathrm{CB}$ ). Van Wyk : 4757.

3. PHYTOLACCACEAE

Limeum viscosum (Gay) Fenzl subsp viscosum var glomeratum (Eckl. and Zeyh.) Friedr.

Herb with small white flowers. Grows on granitic soil in the long grass veld near Pretoriuskop. (Kamban-Komatipoort $2531 \mathrm{AB}$ ). Van Wyk : 4661 .

\section{NYMPHAEACEAE}

Nymphaea caerulea Sav.

Water lily with big blue flowers. Collected in temporary pan in Nwambiya sandveld east of Punda Milia. (Klawerpan-Pafuri 2231 CB). Van Wyk and Pienaar : 4580.

\section{CAPPARIDACEAE}

Boscia angustifolia A. Rich. var corymbosa (Gilg) de Wolf

Small tree which only occurs on sandstone ridges in the Punda Milia area. The leaves which are shed in February, are dull green, hard and mucronate. The fruits are small $(1 \mathrm{~cm}$ diameter $)$, glabrous, slightly rough and yellowish when ripe. The greenish flowers appear with the new leaves in March. (Shantangalane-Pafuri 2231 CA). Pienaar and Van Wyk : 4424, Pienaar : 4708. Vegetative material resembling this species but which could not at the time be identified was previously 
collected in the same locality by Van der Schijff (3704).

Boscia rehmanniana Pest.

Small shrub up to $1 \mathrm{~m}$ high. Leaves very small $(1,5 \times 0,8 \mathrm{~cm})$, narrowly obovate and mucronate. Flowers small. Fruit $1 \mathrm{~cm}$ in diameter, globose, densely pubescent and yellowish-brown when ripe. Collected in the sandveld east of Punda Milia as well as on basalt soil between Tshokwane and Nwanedzi (Lindanda). (Nwambiya-Pafuri $2231 \mathrm{CB}$ and LindandaAcornhoek $2431 \mathrm{DB})$. Brynard and Pienaar : 4305, 4269.

6. LEGUMINOSAE

Acacia luederitzii Engl. var retinens (Sim) Ross and Brenan ( $=$ A. retinens $\mathrm{Sim})$.

Small tree (up to about $8 \mathrm{~m}$ ) with short, hooked thorns in pairssometimes big and swollen due to insect activities; leaves small and resembling that of Acacia tortilis; inflorescence white and globose; pods straight, flat and about $4 \mathrm{~cm} \times 1 \mathrm{~cm}$. Grows on low-lying brackish flats on dolerite soil. Confined to a relatively small area immediately north and north-east of Orpen rest camp. (Orpen-Acornhoek $2431 \mathrm{AD}$ and Kingfisherspruit-Acornhoek 2431 BC). Van Wyk : 4754, 4801.

Newtonia hildebrandtii (Vatke) Torre

Medium-sized tree (up to $20 \mathrm{~m}$ high) with bipinnate leaves, very small white flowers and long, brown, straight pods. Seeds fragile and distinctly winged. Prefers wooded ravines in the Lebombo Mountain (rhyolite). Confined to the mountainous area in the immediate vicinity of the Olifants-Letaba River confluence. (Shinobyene-Phalaborwa 2331 DD). Van Wyk and Pienaar : 4634.

Cassia biensis (Steyaert) Mendonca and Torre

Small herb inhabiting long grassveld near Pretoriuskop (granite). Rare in Kruger Park. (Kamban-Komatipoort 2531 AB). Van Wyk : 4666.

Cassia didymobotrya Fresen.

Large, exotic shrub or small tree with dark-green feathery foliage and conspicuous yellow flowers with unpleasant smell. Occurs in the bed of the Sabie River. (Skukuza-Acornhoek 2431 DC). Pienaar and Van Wyk : 4507.

\section{Caesalpinia decapetala (Roth) Alston}

(= C. sepiaria Roxb.)

Thorny shrub or rambler of up to $6 \mathrm{~m}$ high with bipinnate leaves and yellow flowers. Collected in the beds of the Levubu River west of Punda Milia. Exotic. (Dongadziba-Messina 2230 DB). Van Wyk and Pienaar : 4505 .

Cordyla africana Lour.

Tropical, water-loving tree species which sometimes reaches enormous proportions (crown diameter of about $15 \mathrm{~m}$ ). Confined to the banks and immediate vicinity of the Crocodile River in the area between Crocodile Bridge rest camp and the Lebombo Mountains. Recognised by its shining, feathery, foliage, yellow flowers in clusters and yellow, fragrant, 
edible fruit. Rare in the Kruger National Park. (Crocodile BridgeKomatipoort 2531 BD). Pienaar : 4692.

\section{Indigofera tinctoria $\mathrm{L}$.}

First record of this Asiatic plant in South Africa. Originally cultivated for the manufacturing of indigo. Tends to spread easily. At present known from about all the tropical areas in the world. Introduction into the Kruger National Park most probably by migrating birds. Collected on the banks of the Sabie River a few kilometres east of Skukuza. (Skukuza -Acornhoek 2431 DC). Oakes and Scheepers : 349.

Tephrosia reptans Bak.

Semi-procumbent legume with pale blue flowers. Occurs on granite soil near Pretoriuskop. (Komatipoort $2531 \mathrm{AB}$ and $2531 \mathrm{AD}$ ). Van der Schijff : 1676, 2658.

\section{Pterocarpus antunesii (Taub.) Harms \\ (=P. stevensonii Burtt Davy)}

New record for the Republic of South Africa. Tropical tree species also found in the north of South West Africa. As yet only three specimens recorded in the park-all in the Kalahari-like sand on the Mocambique border east of Punda Milia (Nwambiya sandveld). Leaves pinnate; leaflets relatively small and shining; flowers small and yellow; pods resembling those of $P$. rotundifolius (Sond.) Druce; wood very hard and undifferentiated. (Nwambiya-Pafuri $2231 \mathrm{CB}$ ). D. Lowe : 4641.

7. RUTACEAE

Toddaliopsis bremekampii Verdoorn

Small shrub $(1,5 \mathrm{~m})$ with trifoliate leaves and small, globose, distinctly wrinkled fruits. Collected on sandstone ridge east of Punda Milia. Also known from Mocambique. (Shantangalane-Pafuri 2231 CA). Van Wyk : 4802.

\section{BURSERACEAE}

Commiphora tenuipetiolata Engl.

Tropical tree species occurring on the Lebombo Mountains from the Olifants River gorge northwards to Pafuri-rare in the southern locality but locally abundant in the north. Recognised by its white or yellowish trunk; papery bark; small, yellow, trumpet-like flowers; and shining, red, globose fruits. Prefers rocky situations. (Pafuri-Pafuri 2231 AD, and Olifants River gorge - Phalaborwa 2331 DD).Van Wyk and Pienaar : 4696.

\section{EUPHORBIACEAE}

Drypetes mossambicensis Hutch.

First record for South Africa. Very rare medium sized, (up to $18 \mathrm{~m}$ ) monoecious tree. Grows on termite mounds on grey sandy loam soil in the area adjoining the Nwambiya sandveld to the east of Punda Milia. (Nwambiya-Pafuri 2231 CB). Pienaar and van Wyk : 4625. Also collected in Mocambique (Pafuri 2231 D-Brynard and Pienaar : 4484).

Cleistanthus schlechteri (Pax) Hutch.

Small (up to $7 \mathrm{~m}$ ), monoecious tree in the Kalahari-like sand of the 
Nwambiya area. Occurs mostly in shrub form due to damage by excessive veld burning and elephant depredation. Nwambiya-Pafuri 2231 CB). Van Wyk and Pienaar : 4729.

Pterococcus africanus (Sond.) Pax and Hoffm.

Procumbent herb in sandy soil on mountain slope. (Tula-milaPafuri 2231 AC). Pienaar and Fairall : 4617.

Jatropha variifolia $\mathrm{Pax}$

Vigorous shrub up to $2 \mathrm{~m}$ high. Collected on Shitlave hill east of Pretoriuskop rest camp (dolerite). Rare in Kruger Park. (ShitlaveKomatipoort $2531 \mathrm{AB}$ ). Van der Schijff : 2185.

Euphorbia grandicornis Goeb. ex N.E.Br.

Probably first record for the Transvaal. Spiny succulent up to $1,5 \mathrm{~m}$ high with many, erect and ascending 3-angled branches; angles winglike and up to $7 \mathrm{~cm}$ broad; spines in pairs, very stout and long (up to $6 \mathrm{~cm}$ ). Grows mainly in shade. Confined to a small area in the Lebombo Mountains immediately north of the Olifants River. (Collected in Shinobyene spruit-Phalaborwa 2331 DD). Pienaar : 4886.

Euphorbia monteiroi Hook. f.

Small $(60 \mathrm{~cm})$ thornless shrub with swollen base. Grows amongst rocks on sandy soil (at Shiphale spring) north-east of Punda Milia. (Pafuri 2231 CA). Van Wyk : 4591.

Euphorbia rowlandii R. A. Dyer

Discovered by (about 1932) and named after the late Col. RowlandJones, former senior ranger in the Kruger Park. Type locality: Punda Milia-Kruger National Park. Spiny succulent of about $1 \mathrm{~m}$ high; branches ascending, simple, 4-angled; angles very narrow. Abundant in sandy soil in the dry mountainous area north-north-east of Punda Milia (Madzaringwe-Pafuri $2231 \mathrm{CA}$; also in Pafuri $2231 \mathrm{AC}$ ). Van Wyk : 4887.

\section{CELASTRACEAE}

Maytenus mossambicensis (Klotzsch) Blakelock var mossambicensis

Thorny shrub of about $1 \mathrm{~m}$ high with very small white flowers. Collected in the Kalahari-like sand of Nwambiya east of Punda Milia. (Nwambiya-Pafuri $2231 \mathrm{CB})$. Van Wyk : 4834.

Catha edulis Forsk.

Small to medium-sized tree with linear/elliptic leaves. Flowers and fruits minute. Well known in Arabia and Somalia, because of the stimulating properties of the leaves, twigs and bark. Its effect being such that the French Government had to prohibit the use thereof. Popularly known as Khat. Rare in the park. Possibly introduced because it is only found in the Sabie River at its entrance into the park. (Sabiehoek-Komatipoort 2531 AA). Van Wyk : 4761.

\section{SAPINDACEAE}

Stadmannia oppositifolia Poir. ssp. rhodesica Exell

Reported by Brynard in the previous supplementary check-list as Stadmannia sp. Tree up to $10 \mathrm{~m}$ high. First collected at Mashikiripoort 
(Pafuri 2231 CA) by Brynard and Pienaar (4253). At present known to occur in the entire mountainous area north-west of Punda Milia (sandstone) as well as in a similar habitat to the south but in which the soil was derived from rhyolite-i.e. the mountainous area along the Olifants River from Olifants rest camp to the Mocambique border. (Shinobyene, Bangu, Olifants rest camp).

12. TILIACEAE

Corchorus confusus Wild

Small, semi-twining plant in long grass. Orange-yellow flowers. (Komatipoort $2531 \mathrm{AB}$ ). Le Roux : 4239.

Grewia sp cf. G. flavescens Juss. var olukondae (Schinz) Wild

Shrub up to $2 \mathrm{~m}$ high. Big, shining, serrated leaves. Collected at Mafayeni hot spring in granitic soil. Also seen along the Olifants River in the Lebombo Mountains. (Mafayeni-Pafuri 2231 CC). Van Wyk : 4843.

Grewia sp cf. G. gracillima Wild

Shrub up to $1 \mathrm{~m}$ high. Leaves small and dark green with serrated edges. On sandy soil in the northern area of the park (NwambiyaPafuri $2231 \mathrm{CB})$. Van Wyk : 4885.

\section{MALVACEAE}

Hibiscus meyeri Harv. ssp meyeri.

Small, erect herb with hairy twigs, inconspicuous leaves and purple flowers. Grows in Kalahari-like sand (near Malonga spring) east of Punda Milia. (Nwambiya-Pafuri 2231 CB). Pienaar and Fairall : 4617.

14. STERCULIACEAE

Brachychiton sp nr. B. acerifolium F. Muell.

Exotic shrub up to $1 \mathrm{~m}$ high. Associated with long grass on granitic soil near Pretoriuskop. (Komatipoort 2531 AD). Van der Schijff : 3864.

15. OCHNACEAE

Ochna sp cf. O. atropurpurea DC.

Small shrub with pale yellow flowers and dark-green, hard leaves with serrated edges. Grows in the Kalahari-like sand of Nwambiya. (Nwambiya-Pafuri $2231 \mathrm{CB})$. Van Wyk : 4850.

16. CANELLACEAE

Warburgia ugandensis Sprague

Very rare evergreen tree species on wooded hillsides near Punda Milia (sand). Contains a substance which causes a delayed burning sensation, like pepper, on the tongue. Held in high esteem as medicine plant by the Bantu-known as "shibaha". Leaves dark-green and linear/elliptic; flowers inconspicuous; fruit pear-shaped and purple to black. (Shipudza - Messina 2230 DB). Also seen near Punda Milia-Pafuri 2231 CA. Van Wyk : 4760 .

\section{FLACOURTIACEAE}

Oncoba spinosa Forsk.

Robust, thorny, water-loving shrub with relatively large, attractive, rose-like, white flowers. Collected in riverine forest along the Sabie River. (Skukuza-Acornhoek 2431 DC-Wolhuter : 4606). Also recorded from 
mauve. Fruits 4-winged. Grows in sandy soil amongst rocks in xerophytic forest. Collected near the Levubu River north of Punda Milia. (Papkuilfontein-Messina 2230 DB). Van Wyk : 4635.

\section{ACANTHACEAE}

Ecbolium revolutum (Lindau) C.B.Cl.

Small shrub with greyish-green, hairy leaves and yellow flowers. Found amongst mopane shrubs on basaltic soil at Pafuri. (Pafuri 2231 AD). Pienaar : 4516.

\section{RUBIACEAE}

\section{Enterospermum littorale Hiern}

New record for the Transvaal. Shrub up to 1,5 m high. Leaves hard and shining; flowers minute; berries small, round and black when ripe. Grows in sand in rocky situation. Widespread in the Punda Milia and Nwambiya sandveld regions. (Collected at Shantangalane-Pafuri 2231 CA). Van Wyk : 4765.

\section{Zygoon graveolens Hiern}

Small shrub (1 m high) in Nwambiya sandveld. Flowers and fruit inconspicuous. Previously erroneously identified as Tricalysia allenii. (Nwambiya-Pafuri 2231 CB). Van Wyk : 4724.

\section{Canthium setiflorum Hiern}

Woody shrub (about $2 \mathrm{~m}$ high) in xerophytic forest (Androstachys johnsonii Prain) on rhyolitic soil. Leaves small and scattered; flowers and fruits very small and inconspicuous. (East of Mahlakuza pan-Pafuri $2231 \mathrm{CB})$. Van Wyk and Pienaar : 4571.

Pachystigma macrocalyx (Sond.) Robyns

Shrub (up to $2 \mathrm{~m}$ high) in sandy soil (Nwambiya). Leaves large, soft and hairy; fruit globose $(2,5 \mathrm{~cm}$ diameter), dark-green and shiningresembling that of Vangueria infausta Burch. (Nwambiya-Pafuri 2231 CB). Van Wyk and Pienaar : 4695.

\section{Pavetta microlancea K. Schum.}

Small shrub $(30 \mathrm{~cm})$ with dark spots (bacterial nodules) in the leaves. Very attractive when in full bloom. Flowers white. Grows on basalt plains near Crocodile Bridge restcamp. (Krokodilbrug-Komatipoort 2531 BD). Van Wyk : 4753.

\section{COMPOSITAE}

Vernonia sp cf. $V$. poskeana Vatke and Hildebr.

Erect herb (75 cm high) with very narrow, linear leaves and purple flowerheads. Found on granitic soil in long grass veld near Pretoriuskop restcamp. (Kamban-Komatipoort $2531 \mathrm{AB}$ ). Van Wyk : 4684.

Helichrysum foetidum (L.) Cass.

Erect herb (1 m high) with yellow flowers. On granite soil near Pretoriuskop. Previously identified as $H$. sp. cf. $H$. decorum DC and $H$. setosum Harv. (Komatipoort 2531 AB). Van der Schijff : 2655. 


\section{REFERENCES}

BRYNARD, A. M. 1961. A supplementary check list of plants recorded in the Kruger National Park. Koedoe 4: 110-116.

VAN DER SCHIJFF, H. P. 1957. 'n Ekologiese studie van die flora van die

Nasionale Krugerwildtuin. D.Sc. thesis, Potchefstroom University for C.H.E. 